\title{
Exploration Of Matematical Concep And Natural Sciences From The Local Wisdom Of Society As Learning Materials In The Curriculum 2013
}

\author{
Marianus ${ }^{1}$, Damaris ${ }^{2}$ \\ 1,2 Department of Physics, Faculty of Mathematics and Natural Sciences, \\ Universitas Negeri Manado, Indonesia \\ corresponding author: ${ }^{1}$ marianus @ unima.ac.id
}

\begin{abstract}
The population growth is closely related to the utilization of natural resources and will impact on environmental degradation. Therefore, identifying and inventorying the local wisdom of the community that aims to conserve the environment is very important. Natural science perspective lifting local wisdom in education is one way to revitalize, develop and maintain the values of local knowledge. This study aims to explore the elements of local wisdom in society, examines the concept of Natural Science and Mathematics contained in the elements of local wisdom and is designed for learning materials. The research was conducted in the District Manganitu Sangihe Islands in January 2016. Data collection using observation techniques and interviews with related parties and data obtained analyzed the concept of science underlying the forms of local wisdom existing in Manganitu community.The result of the research is a concept map which contains the network of Mathematics and Natural Science concepts. This research product can meet the needs of high school teachers and become one of the solution of thematic learning problem in Sangihe Island.
\end{abstract}

Keywords : Concept of Mathematics and Science, Local Community Wisdom, Curriculum 2013

\section{Introduction}

Implementation of the 2013 curriculum demands changes in learning(Anonymous.2012). The core of the 2013 curriculum, there is an integrative and thematic simplification effort and more focus on character education. in line with this curriculum change, science-mathematics learning also undergoes a change, and leads to integrated science learning and using the theme as the one material in several subjects at once in one meeting (H.M. Zuhdi, 2012)

Now this is one of the problems in the implementation of the 2013 curriculum is the unavailability of teaching materials in accordance with the 
demands of the curriculum(Sartono.2012). In its structuring and refinement, the 2013 curriculum focuses more on natural, social, artistic and cultural phenomena, including local wisdom of society (Patimah Tandjung, edall.2018).

According to Francis Wahono (2005) local wisdom is the intelligence and management strategy of the universe in maintaining the ecological balance that has been tested for centuries by various disasters and obstacles and negligence of humans. Local wisdom not only stops ethics, but comes to the nomads of action and behavior, so that local wisdom can be like a religion that guides people in attitude and action, both in the context of everyday life and determines the further human civilization (Suastra, et all.2017). Raising local wisdom as an object in education is one way to revitalize, maintain and develop the values of local wisdom. Local wisdom-based education means utilizing the elements of local wisdom to be incorporated into the curriculum, and aims to provide knowledge, skills and behavior to learners so that they have a solid insight into the state of the environment and the needs of the community in accordance with the rules prevailing in and to support regional development and national development (Andam S.2016). Developing teaching materials from local community wisdom means preserving local culture and elevating the locals' positive local wisdom (Laode Monto Bauto, 2013).

According Suhartini (2009: 9), learning local wisdom has a strategic position, namely: 1) The local wisdom of one of the formers of identity; 2) Local wisdom is not a value unfamiliar to the owner; 3) The emotional involvement of the community in the appreciation of strong local wisdom. 4) Local wisdom is able to grow self-esteem; and 5) Local wisdom can improve the treasures of the nation and the State.

The five things above if guided by the guide in preparing a teaching materials, then not only a big influence on people who menga a certain local wisdom but also very influential on learning in this case is the student. Education based on local wisdom, make students more active and create a fun learning atmosphere. Local wisdom-based education can contribute the nature of the learner's responsibility to himself, to his or her environment and even to his or her social environment, and especially to his responsibility as an individual who believes in God Almighty.

The objectives of this research were:1) To explore the elements of local wisdom in society, 2) To examines the concept of Natural Science and Mathematics contained in the elements of local wisdom; and 3) To create a network of concepts in the form of concept maps. 
Journal of Educational Method and Technology Vol. 1 No. 2, September 2018

P-ISSN 2622-8459 E-ISSN 2622-8467

http://ejournal.unima.ac.id/index.php/jemtec

\section{Methods}

This research is an explorative -analitical research (Sugiyono, 2015). Explore the local forms of local wisdom and identify the science and mathematical concepts relevant to the elements of local wisdom. Analyzing the conceptual (IPA and Mathematics) fabric in each element of local wisdom and designing it as a learning material stage. Analyzing and formulating the concept of conceptual interwoven in a concept mapping.

Objects in this study are forms of local wisdom in society and concepts of science relevant to local wisdom. Local wisdom in a society includes elements such as local skills, local customary customs, local ethical norms as well as sanctions for violations, local knowledge, forms of social relations or local social processes and local resources.

Data collection with simple qualitative methods, including procedures: 1) To observe, identify and classify local wisdom forms of society in Manganitu Sub-district; and 2) Conducting interviews with community leaders and teachers in Manganitu sub-district about the history of local wisdom, people who still hold on to local wisdom, factors that lead to degradation of values, knowledge (rationality of local wisdom), regulations, obligations, prohibitions and sanctions.

Analysis Method inclusing: 1)Activity identification forms - forms of local wisdom; 2) Analysis of the form of elements of local wisdom. 3) Analyze the concepts of science and mathematics that are relevant to the elements of local wisdom; and 4)Analysis of conceptualization for conceptual map formulation, as well as analysis of the potential contribution of learning activities to the improvement of knowledge, skills and affection.

\section{Results and Discussion}

This research resulted in a description of local wisdom as much as 22 , the translation of science and mathematics, and network concept in the form of concept maps. Local wisdom includes musical instruments, customary rules and sanctions for violations, handicrafts, legend stories, traditional medicine and community habits in utilizing natural resources. Of the description results presented only one type of local wisdom is the use of Londe Boat.

\section{A. General description of Londe Boat.}

There are 2 types of boats that have existed since ancient times in the District Manganitu. In the process of making it there is no guide how the boat, but the making of boats based on knowledge from generation to generation. The wood is used as a souring boat material that is durable wood species such as gumahe, plata, panirang, nantu and dingkaleng.Pada side of the boat is installed sema from bamboo to maintain the balance. Both types of boats are using the screen from 
Journal of Educational Method and Technology Vol. 1 No. 2, September 2018

P-ISSN 2622-8459 E-ISSN 2622-8467

http://ejournal.unima.ac.id/index.php/jemtec

tetron fabric. The londe boat has a long tapered shape on the front and a short pointed rear. While boats have a simpler shape on the front and rear does not have a difference. (Source: Arnol Tasumaro, 2016).

\section{B. Analysis of the Concept of Science}

Theme: Boat

Component / Sub Theme

1. The Law of Archimedes

Facts / phenomena:

The boat floats on the water.

Variable:

Floating Style

Temporal Variation:

The deeper the fluid the greater the pressure.

Factors that influence and shape relationships:

The mass of the object is less than the density of the liquid, the buoyant force will be greater than the gravity of the object. Floating force is an upward force that is affected by pressure.

\section{Newton's Law III}

Facts / phenomena:

The boat is driven by oars

Variable:

The driving force

Factors that influence and shape the relationship;

The muscle force applied to the water is the same as the thrust of water given to the boat.

\section{Friction}

Facts / phenomena:

Boats moving on the water, londe boats more speed than boat pelang.

Variable:

Coefficient of kinetic friction $\left(\mu_{k}\right)$

Factors that influence and shape relationships:

The more coarse the two plane touched the greater the coefficient of friction.

The sharper the front of the boat the smaller the frictional force.

\section{Description Linkages Concept}

Floating force occurs because of differences in fluid pressure at different depths. The deeper the fluid (the liquid) the greater the pressure. This is in accordance with the law of Archimedes which reads "objects inserted or 
Journal of Educational Method and Technology Vol. 1 No. 2, September 2018

P-ISSN 2622-8459 E-ISSN 2622-8467

http://ejournal.unima.ac.id/index.php/jemtec

immersed in part or all of them in a liquid will obtain a force which is upward and equal to the weight of the liquid transferred by the object". What is meant by the upward force is the buoyant force. Mathematically written as follows:

$$
\begin{aligned}
& F_{A}=W_{b f} \\
& F_{A}=\text { the upward force } \\
& W_{b f}=\text { the weight of the removed liquid } \\
& \text { Because } W_{b f}=m_{b f} g \text { and } m_{b f}=P_{f} V_{B F}
\end{aligned}
$$

Then:

$\mathrm{F}_{\mathrm{A}}=\mathrm{P}_{\mathrm{f}} \mathrm{V}_{\mathrm{bf}} \mathrm{g}($ Lusiana Dwi dan Fitri Yulianto.2011)

Where :

$\mathrm{P}_{\mathrm{f}}=$ the density of the fluid $\left(\mathrm{kg} / \mathrm{m}^{3}\right)$

$\mathrm{V}_{\mathrm{bf}}=$ the volume of liquid displaced $\left(\mathrm{m}^{3}\right)$

$\mathrm{g}=$ earth's gravitational acceleration $\left(\mathrm{m} / \mathrm{s}^{2}\right)$

The buoyant force depends on the density of the fluid and the amount of fluid displaced by the object. Mass density is the ratio between the mass and volume of the object.

\section{The boat floats on water (Case Floating objects)}

The object floats on the surface of the water if the density of the body is less than the density of the liquid, the buoyant force will be greater than the weight of the object. In this case, only a portion of the volume of the object is immersed in the liquid so that the volume of the moving liquid is smaller than the total volume of the floating object. Since the volume of the dyed object is smaller than the total body volume, the condition of the floating object is:

The floating force of the $\mathrm{Fa}$ is equal to the weight of the object $\mathrm{w}$ or $\mathrm{Fa}=\mathrm{w}$ as well as the density of the different type must be less than the mass of the fluid type or $\rho b<\rho f$ generally:

$$
\begin{aligned}
& \rho b, \text { average }=\rho f \\
& \rho b, \text { rata-rata }=\rho f \\
& w=F a
\end{aligned}
$$

Where :

$$
\begin{aligned}
& \rho \mathrm{b}=\text { mass of objects } \\
& \rho \mathrm{f}=\text { the density of the fluid } \\
& \mathrm{w}=\text { weight of objects } \\
& \mathrm{Fa}=\text { Floting force }
\end{aligned}
$$




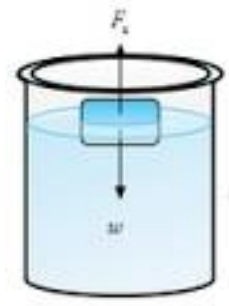

Floating Object

$\mathrm{Fa}>\mathrm{W}$

Figure 1. Floting Object ( http://alisabana.blogspot.com/2012/05/penerapan-hukum-archimedes-padakapal.html, by Ali Sabana.)

Boats pelang and londe has a hull with a hydrostatic type, where on the inside of the boat shaped space, most of the stomach soaked in water. The speed is relatively low because it must overcome the large water resistance.

Because the shape of the boat is hydrostatic (has space) so that free air moves, making the density of the boat is smaller than the sea water type. Or when the boat is in the sea surface bag, the boat puts pressure on the water, the weight of the boat presses the water down, with the same force of water putting pressure on the boat and this force is in opposite direction with the gravity of the boat.

The factors that most affect the speed of the boat are the booster's thrust, the motion of the boat over the sea surface is applicable to Newton's III Law of reaction action. Newton's Law III states that "if the first object does the force (action) of the second object then the second object will act on the first object of the same force, but the direction is opposite",

$$
\sum F_{a k s i}=-\sum F_{\text {reaksi }}(\text { Purnomo,et all.2000). }
$$

The negative (-) indicates both opposite directions.

So in Newton III law apply the following things:

a. There are two forces that work on two objects.

b. Both Forces have the same magnitude.

c. Both Forces have opposite directions.

When we are on a boat and want the boat to move toward the front, we have to force the water by rowing backward, this means we make efforts on water, so that the force given on the water through the rower (action force) will be responded by water put pressure on the rower (action style) so that the boat is pushed forward (the boat is moving).

If a force (F) causes the displacement of the boat as far as $\mathrm{s}$, then the force $\mathrm{F}$ to do work at, namely:

a. The direction of force $\mathrm{F}$ is equal to the direction of movement (s) : W $=$ Fxs

b. Component $\mathrm{F}$ in the direction of displacement is $\mathrm{F} \cos \alpha$, Work: 
Journal of Educational Method and Technology Vol. 1 No. 2, September 2018

P-ISSN 2622-8459 E-ISSN 2622-8467

http://ejournal.unima.ac.id/index.php/jemtec

$$
\mathrm{W}=(F \cos \alpha) \cdot s=F \cdot s \cos \alpha
$$

Where:

$\mathrm{W}=$ Work $(\mathrm{j})$

$\mathrm{F}=$ Force $(\mathrm{N})$

$\mathrm{s}=$ displacement $(\mathrm{m})$

$\alpha=$ angle between force and displacement

1 joule $=1 \mathrm{~N} \cdot \mathrm{m}$ (Newton-meter).

When the boat begins to move towards the front then the bottom surface of the boat will rub against the water causing a frictional force. Friction force is a force that arises from direct contact between two surface objects in the opposite direction to the tendency of the direction of motion of the object.

Friction :

$$
\begin{aligned}
& f_{\text {riction }}=\mu \cdot N \cdot m \cdot g \\
& \mu=\frac{f_{g}}{N}
\end{aligned}
$$

Where:

$\mu=$ friction coefficient

$\mathrm{N}=$ normaly force

$\mathrm{M}=$ massa

$\mathrm{g}=$ Force of gravity

The friction force that arises between the plane of the boat contact and water is the kinetic frictional force (fk). kinetic frictional force is the frictional force that arises when two objects rub against each other in a state of relative relative to one another. This friction force fights the outer force of $\mathrm{F}$ so that it inhibits the object when the object is already moving. So this frictional force wasted the boat as the boat began to move.

$$
F_{k}=\mu_{k^{*}} N
$$

Where:

$\mathrm{F}_{\mathrm{k}}=$ kinetic frictional force $(\mathrm{N})$

$\mu_{k}=$ The kinetic coefficient of friction

$\mathrm{N}=$ the normal force $(\mathrm{N})$

If the resultant outer force horizontal $\mathrm{F} \leq \mathrm{f} \_\mathrm{s}$ is an object moving at velocity $\mathrm{V}$ and the friction force that occurs on the object is the kinetic frictional force (fk) ... The londe and sashboards are made spiky at the front ends aiming to reduce the 
Journal of Educational Method and Technology Vol. 1 No. 2, September 2018

P-ISSN 2622-8459 E-ISSN 2622-8467

http://ejournal.unima.ac.id/index.php/jemtec

frictional force occurring between the boat and water. According to the local community lava boats faster than the boat pelang, this speed difference is due to londe boats have a more pointed front. While the sema on the right and left sides of the boat serve to keep the boat in equilibrium or moving equilibrium. The boat body can be described as a material or particle point. Can be described as follows:

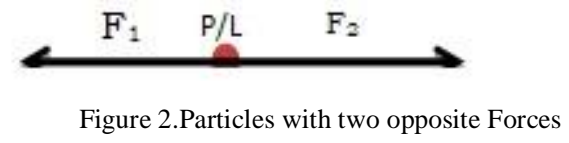

$$
\begin{aligned}
& \mathrm{P} / \mathrm{L}=\text { pelang } / \text { londe } \\
& \left.\mathrm{F}_{1}=\text { Force } 1 \text { (sema-sema } 1\right) \\
& \mathrm{F}_{2}=\text { Forces } 2 \text { (sema-sema } 2 \text { ) }
\end{aligned}
$$

The picture 2 above shows two forces (sema-sema) that work on particles (boats). These two styles work in line, as great and counterclockwise. So the boat at first kept silent in silence. Therefore, the requirement for a balanced particle is the resultant force acting on the object equal to zero.

Newton's law states, if a resultant force acting on an object is equal to zero, no object at rest or moving straight uniform. Based on Newton's first law, if the state of the particles meet:

$$
\begin{aligned}
& F_{x}=0 \\
& F_{y}=0 \\
& v=0
\end{aligned}
$$

Mean particle at rest and said particles in static equilibrium state. If the particle state meet:

$\mathrm{F}_{\mathrm{x}}=0$

$\mathrm{F}_{\mathrm{y}}=0$

$\mathrm{v}=$ constant

Means the object in a balanced state dynamic (translation). In short it can be said the terms balanced objects (particles) are:

$$
\begin{aligned}
& \sum F_{x}=0 \\
& \sum F_{y}=0
\end{aligned}
$$

In accordance with Newton's Law, balanced objects $(\Sigma \mathrm{F}=0)$ do not require objects to be stationary, but particle acceleration must be zero or constant velocity. 
Journal of Educational Method and Technology Vol. 1 No. 2, September 2018

P-ISSN 2622-8459 E-ISSN 2622-8467

http://ejournal.unima.ac.id/index.php/jemtec

D. Concept maps

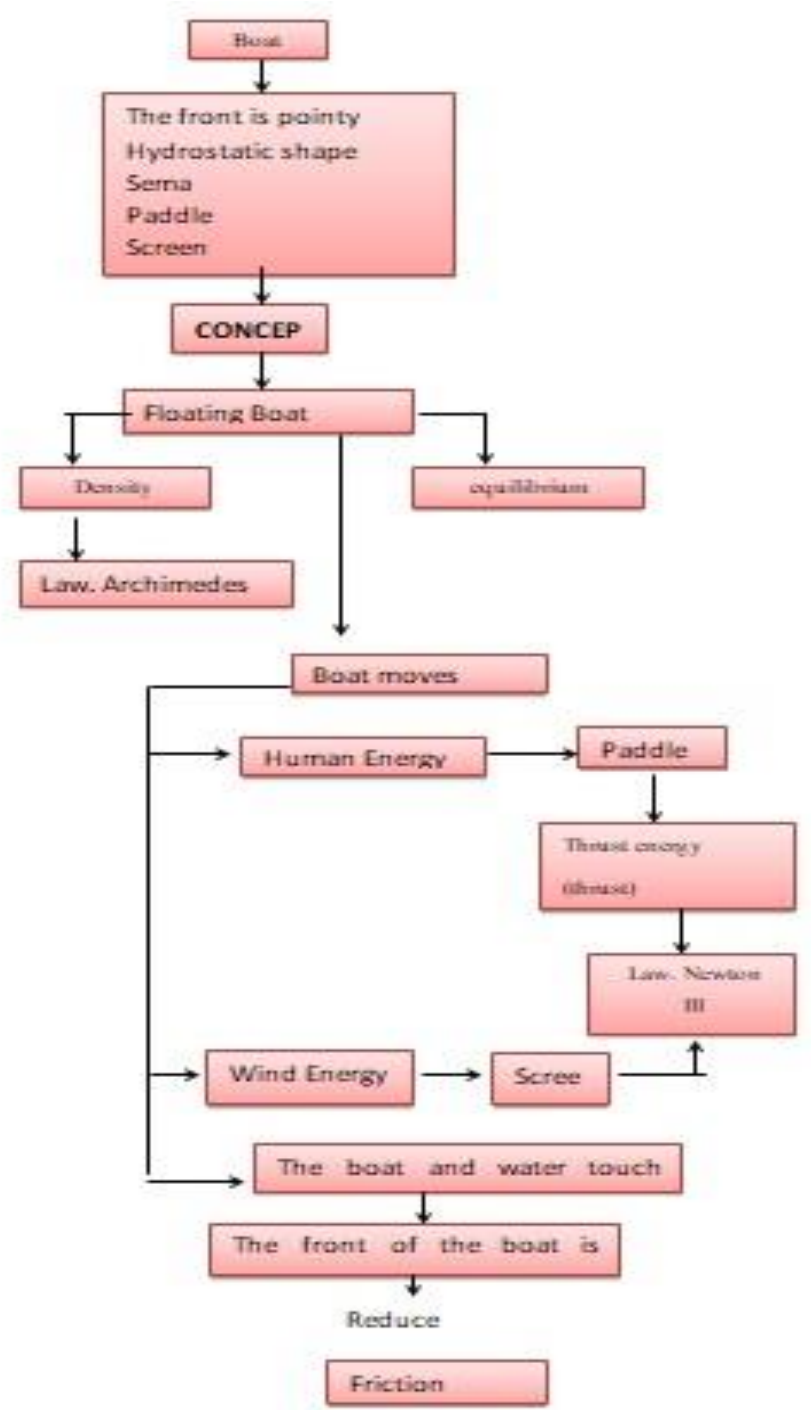

Figure 3. Concept Mapping

\section{E. Potential Contribution in Curriculum 2013}

Facts / Phenomena

1. Boats float on water

Concept: The Law of Archimedes

Subjects that match the curriculum 2013: Physics of high school class X second semester.

2. Boats are driven by paddles and screens

Concept: Newton's Law

Energy in the living system 
Journal of Educational Method and Technology Vol. 1 No. 2, September 2018

P-ISSN 2622-8459 E-ISSN 2622-8467

http://ejournal.unima.ac.id/index.php/jemtec

Subjects corresponding to the curriculum-lum 2013: Physics of first semester $\mathrm{X}$ grade $\mathrm{X}$ and IPA Integrated junior high school class VII first semester.

3. Rowing to move the boat position

Concept: Work

Subjects that match the curriculum-lum 2013: Physics of high school class

XI first semester

4. Londe boats move faster than the pelang boats

5. Concept: Friction

Subjects that match the curriculum-lum 2013: Physics High School X class semester first.

6. The boat has two semas

Concept: Equilibrium of Rigid Objects

Subjects that match the curriculum-lum 2013: Second Class Physics of second semester XI.

7. Boats are made of certain types of wood Concept: Biodiversity Utilization Hayati.

Subjects that match the curriculum 2013: Biology of high school grade X of the first semester.

8. Boats using fuel (gasoline and diesel)

Concept: Impact of Fuel Burning

Subjects that are in line with the 2013 curriculum: Chemistry High School grade XI first semester.

\section{General Discussion}

The Sangihe Islands have various forms of local wisdom. People\&\#39;s lives are still strongly influenced by the traditions and customs of their ancestors. The abundance of natural resources in the island of Sangihe makes the community more dependent on nature.Tradisi dipertahankan make the community more wise in utilizing natural resources. Related to local wisdom-based education, the traditions and customs of society can be contributed in learning, by analyzing the basic concepts of science and mathematic. The results of this study can be adopted and developed by high school teachers and senior high schools to support government programs in order to succeed learning thematic learning based on local wisdom applied in the curriculum 2013.

\section{Conclusion}

Based on the results of exploration and discussion then it can be concluded: The community of Sangihe Islands is more special in the community Manganitu District still has various forms of local wisdom to preserve the environment. The wisdom of local wisdom is very rich with the concept of science and mathematics 
Journal of Educational Method and Technology Vol. 1 No. 2, September 2018

P-ISSN 2622-8459 E-ISSN 2622-8467

http://ejournal.unima.ac.id/index.php/jemtec

that can be explored and designed as learning materials for junior and senior high school.

Suggestion for the Government and communities of the Sangihe Islands Regency to maintain and preserve existing local wisdom to support science and mathematics education.

\section{References}

Andam S. Ardan.2016. The Development of Biology Teaching Material Based on the Local Wisdom of Timorese to Improve Students Knowledge and Attitude of Environment In Caring the Persevation of Environment.International Journal of Higher Education Vol. 5, No. 3; 2016 Published by Sciedu Press 190 ISSN 1927-6044 E-ISSN 1927-6052.

Anonymous.2012. Kearifan Lokal Sebagai Baha-

n Ajar Bahasa Indonesia Bagi Penutur As-

ing.(http://rytemis.wordpress.com/2012/02/09/kearifanlokalsebagai bahanajar bahasa-indonesia-bagipenuturasing/)diuduh pada 17 November 2016.

Fauzana. 2011. Peranan Kearifan Lokal dalam Pembangunan.(http://fauzana.blo gspot.com/2011/10/03/peranan-kearifan-lokal-da-lam.html), diunduh pada 17 November 2016.

I. W. Suastra, B. Jatmiko, N. P. Ristiati, L. P. B. Yasmini.2017. Developing Characters Based on Local Wisdom of Bali in Teaching Physics in Senior High School. Jurnal Pendidikan. Indonesian Journal Science Vol 6, No 2 (2017).

Laode Monto Bauto.2013. Socio Cultural Values as Community local wisdom Kotoda Muna in the Development of learning material sosial studies and History.Historia,Jurnal Pendidikan dan peneliti sejarah vol 14.no.2 2013,eISSN.2615-7993.

Patimah Tanjung, Syahnan Daulay, Oky Fardian Ghafari.2018. THE DEVELOPMENT OF LOCAL WISDOM OF LABUHANBATU BASED ON TEACHING MATERIAL OF DESCRIPTIVE TEXT FOR 7TH GRADE STUDENT AT SMP NEGERI 1 BILAH BARAT, International Journal of Education, Learning and Development Vol.6, No.1, pp.80-92, January 2018 _ Published by European Centre for Research Training and Development UK (www.eajournals.org) 80 Print ISSN: ISSN 2054-6297, Online ISSN: ISSN 2054-6300.

Purnomo Imam dkk.2000.Konsep-konsep Fisika kelas 3 SMU.Klaten : Intan Pariwara.

R. Lusiana Dwi dan Fitri Yulianti. 2011. Inovasi Tanpa Batas Fisika SMA/MA kelas X,XI,XII.Yogyakarta: Kendi Mas Media. 
Journal of Educational Method and Technology Vol. 1 No. 2, September 2018

P-ISSN 2622-8459 E-ISSN 2622-8467

http://ejournal.unima.ac.id/index.php/jemtec

Sabana

Ali.2012.Penerapan

Hukum

Archimedes.

(http://alisabana.blogspot.com/2012/05/

penerapanhukumarchimedespadakapal.html), diunduh pada tanggal 10 Maret 2016.

Sartono. 2012. Menyongsong Kurikulum 2013.

(http://sartono.blogspot.com/2012/12/15/MenyongsongKurikulum 2013.htm), diunduh pada tanggal 17 November 2016.

Suhartini.2009. kajian kearifan lokal masyara-

kat dalam pengelolaan Sumberdaya alam dan lingkungan. (http://staff.uny.ac. id/sites/default/files/penelitian/Ir.\%20Suhartini,\%20MS./Shtn\%20Semnas\%2

0MIPA\%2009\%20Kearifan\%20Lokal.pdf) diunduh pada tanggal 16

September 2016.

Sugiyono. 2015. Metode Penelitian Pendidikan. Bandung: Alfabeta.

Zuhdi, H. Mohammad. 2012.Pembelajaran Tematik (http://www.academia.edu/47 62544/pembelajarantematik) diunduh pada tanggal 17 November 2016. 